\title{
INCIDENCE RATE OF MUSCULOSKELETAL INJURIES IN BRAZILIAN
} ARMY

\section{TAXA DE INCIDÊNCIA DE LESÕES MUSCULOESQUELÉTICAS NO EXÉRCITO BRASILEIRO}

\section{Eduardo Borba NEVES ${ }^{1}$; Rafael Chieza Fortes GARCIA ${ }^{2}$; Rafael Melo de OLIVEIRA ${ }^{3}$; Eduardo Camillo MARTINEZ}

1. Fisioterapeuta, Doutor em Engenharia Biomédica, Instituto de Pesquisa da Capacitação Física do Exército -IPCFEX, Rio de Janeiro, RJ, Brasil; 2. Médico, Especialista em Medicina Física e Reabilitação - IPCFEX, Rio de Janeiro, RJ, Brasil; 3. Educador Físico, Mestre em Ciências da Atividade Física - IPCFEX, Rio de Janeiro, RJ, Brasil; 4. Educador Físico, Doutor em Saúde Pública - IPCFEX, Rio de Janeiro, RJ, Brasil.

\begin{abstract}
The incidence of musculoskeletal injuries (MSIs) is a constant concern in all Armed Forces. Among risk factors for MSIs, physical training and sports can be considered the most frequent cause in military. In this sense, the aim of this study was to investigate the incidence rate of musculoskeletal injuries, identifying the anatomical distribution and its association with risk factors such as: body composition, age and physical training over the past 12 months. Three hundred fifty-one male cadets from the first year of the Brazilian Army officers training course and four hundred and fifty six students from the logistics sergeants training course (three hundred seventy-five male and eighty one female) volunteered to fill in a self-reported questionnaire which was developed based on a literature review and the clinical experience of the investigators. It contained questions concerning anatomical site of the MSIs, hours of physical activities per week, type of activities at the moment of injury and days of absences in physical activities. Among 807 subjects studied, 180 military have reported 220 MSIs. From this total, 143 have presented a single injury, 34 have suffered two injuries and three subjects have had three injuries each one during the last 12 months. Knee was the anatomical site with the higher incidence $(7.06 \%)$ of MSIs over a 12-month period. Running was the activity with the higher incidence (11.77\%) of injuries over a 12-month, accounting for $43.18 \%$ of all MSIs. When considered all activities of physical training, the MSIs incidence rate over a 12 -month was $17.97 \%$, which represents $71.36 \%$ of all MSIs. In young militaries, the largest amount musculoskeletal injuries occurred in the lower extremities and during military physical training, with running being the main activity in which the injuries occurred. Population, gender and body composition was not significantly associated with these types of injuries, while older age was associated in this study. The gradual and systematic progression of distance and speed during running training should be emphasized to prevent MSIs.
\end{abstract}

KEYWORDS: Musculoskeletal injuries. Military personnel. Epidemiology. Risk factors. Wounds and injuries.

\section{INTRODUCTION}

The incidence of musculoskeletal injuries (MSIs) is a constant concern in all Armed Forces. Several countries have developed studies to identify risk factors for the occurrence of injuries. Some of them are already testing strategies to minimize these risk factors, and therefore, the incidence of this type of injury (KOTWAL, 2012; GOODALL et al., 2013; BULZACCHELLI et al., 2014).

The Brazilian Army (BA) currently has approximately, 220.000 militaries on its permanent staff. Daily military activity covers a variety of situations ranging from administrative work to operational activities with high physical demand (NEVES, 2007; NEVES; MELLO, 2009). The physical preparation is one of the principal responsibilities of the military work, not only during possible conflicts, for which they must always be prepared, but also in times of peace, requiring them high level of physical and mental health (NEVES; MELLO, 2009; ORR et al., 2015).
Authors describe: sociodemographic characteristics, body mass index, medical history, cardiovascular fitness, neuromuscular fitness, gender and lifestyle factors as the main risk factors to development of MSIs (BULZACCHELLI et al., 2014; KODESH et al., 2015). Among these risk factors, physical training and sports can be considered the main cause of MSIs. Nindl et al. (2013) investigated the causes of non-battle injuries (NBIs) which have promoted medical evacuations from recent US Army theaters of operation and they reported most of MSIs (56\%) was directly related to physical training. Same authors support higher levels of physical fitness can act as protect factor against MSIs, however, physical training in excess, aiming to improve fitness can raise injury rates.

There are evidences that the body mass index is also a risk factor for injuries (KNAPIK et al., 2013; KNAPIK, 2015). However, there are few studies on the incidence of lesions in the Brazilian army, and they are restricted to small specific subpopulations, such as the paratroopers (NEVES et al., 
2009; NEVES et al., 2010). In this sense, the aim of this study was to investigate the incidence rate of musculoskeletal injuries, identifying the anatomical distribution and its association with risk factors such as: body composition, age and physical training over the past 12 months.

This knowledge is a crucial step to plan strategies to reduce physical training related injuries and may reduce the time out of work, health costs and discharges from the Army. In this sense, the aim of this study was to investigate the incidence rate of musculoskeletal injuries, identifying the anatomical distribution and its association with risk factors such as: body composition, age and physical training over the past 12 months.

\section{MATERIAL AND METHODS}

Three hundred fifty-one male cadets from the first year of the Brazilian Army officers training course and four hundred and fifty six students from the logistics sergeants training course (three hundred seventy-five male and eighty one female) volunteered to participate in the study. The inclusion criteria were: the participant should have more than one and less than two years of experience in military activities, and should be volunteers to fill out the self-reported questionnaire. Following an explanation of all procedures, risks and benefits, each volunteer signed their informed consent form to participate in the study. The study protocol followed the procedures of the Helsinki declarations and it was approved by a Human Research Ethics Committee under CAAE number 53694016.9.0000.5250. The anthropometric characteristics of the sample were (average \pm standard deviation): male [age of $21.14 \pm 2.12$ years; weight of $72.94 \pm 8.18 \mathrm{~kg}$, height of $1.76 \pm$
0.06 meters, body mass index of $23.53 \pm 2.00$ ] and female [age of $23.51 \pm 2.51$ years; weight of $61.30 \pm$ $8.46 \mathrm{~kg}$, height of $1.64 \pm 0.07$ meters, body mass index of $22.74 \pm 3.00]$.

Information were collected by self-reported questionnaire which was developed based on a literature review and the clinical experience of the investigators (PATTUSSI et al., 2008; PAPACHRISTOS et al., 2014). It contained questions concerning anatomical site of the MSIs, hours of physical activities per week, type of activities at the moment of injury and days of absences in physical activities.

Descriptive statistics were used to summarize the characteristics of the studied sample and Shapiro-Wilk test was performed to exam the variables distribution (RAZALI; WAH, 2011). Pearson qui-square test $\left(\chi^{2}\right)$ was used to compare the Incidence rate $(\%)$ of MSIs among anatomical site of MSIs, type of activities at the moment of injury and gender. The relative risk (RR) for MSIs was calculated for subgroups (determined by the quartiles (KNAPIK, 2015)) stratified by age, hours of physical activities per week and body mass index. The Statistical analyses were performed with Statistical Package for Social Sciences (SPSS, version 21.0). The statistical significance level was defined as $\mathrm{p}<0.05$.

\section{RESULTS}

Among 807 subjects studied, 180 military have reported 220 MSIs. From this total, 143 have presented a single injury, 34 have suffered two injuries and three subjects have had three injuries each one. Table 1 shows the injuries prevalence according to anatomical site, as well as averages of time away from physical activity.

Table 1. MSIs incidence over a 12-month period and time away from physical activity according to anatomical site from 180 military of 807 studied, 2015, Brazil.

\begin{tabular}{cccc}
\hline Anatomical Site & $\mathbf{N}$ & Incidence rate (\%) & Days of absence from physical training/sport (Average \pm SD) \\
\hline Head & 3 & 0.37 & $19.33 \pm 14.36$ \\
Neck & 1 & 0.12 & 7 \\
Trunk & 8 & 0.99 & $25.13 \pm 51.02$ \\
Shoulders & 37 & 4.58 & $16.68 \pm 22.85$ \\
Arm / Elbow & 4 & 0.50 & $34.50 \pm 40.72$ \\
Wrist / Hands & 11 & 1.36 & $22.00 \pm 28.06$ \\
Hip & 4 & 0.50 & $20.25 \pm 20.84$ \\
Thigh & 6 & 0.74 & $17.67 \pm 23.10$ \\
Knee & 57 & 7.06 & $24.19 \pm 41.03$ \\
Leg & 22 & 2.73 & $17.38 \pm 21.64$ \\
Ankle & 47 & 5.82 & $19.96 \pm 20.49$ \\
Feet & 20 & 2.48 & $15.60 \pm 14.18$ \\
\hline
\end{tabular}


There was a significant difference among the Incidence rate $(\%)$ of MSIs in each body region $\chi^{2}(11)=214.98(\mathrm{p}<0.001)$ and also when considered the six most frequents (Shoulders, Wrist / Hands, Knee, Legs, Ankle and Feet) $\chi^{2}(5)=49.91$ $(\mathrm{p}<0.001)$. Knee was the anatomical site with the higher incidence $(7.06 \%)$ of MSIs over a 12-month period. The sample was also stratified by type of activities at the moment of injury. These results were presented in Table 2.

Table 2. MSIs incidence over a 12-month period according to type of activities at the moment of injury from 180 military of 807 studied, 2015, Brazil.

\begin{tabular}{cccc}
\hline Type & Activity & N & Incidence rate (\%) \\
\hline & Camp activity & 27 & 3.35 \\
& Physical training (pull up) & 5 & 0.62 \\
Physical training (running) & 95 & 11.77 \\
& Physical training (collective sports) & 22 & 2.73 \\
& Physical training (individual sports) & 18 & 2.23 \\
& Physical training (military pentathlon obstacle run) & 5 & 0.62 \\
& Military instructions & 29 & 3.59 \\
& Others military activities & 3 & 0.37 \\
\hline \multirow{3}{*}{ Out of military activities } & Running & 6 & 0.74 \\
& Physical training (collective sports) & 3 & 0.37 \\
& Physical training (individual sports) & 3 & 0.37 \\
& Others activities & 4 & 0.50 \\
\hline
\end{tabular}

There was a significant difference among the proportions of MSIs during military activities $\chi^{2}(7)=245.49(\mathrm{p}<0.001)$. Running was the activity with the higher incidence $(11.77 \%)$ of injuries over a 12 -month, accounting for $43.18 \%$ of all MSIs. When considered all activities of physical training, the MSIs incidence rate over a 12 -month is $17.97 \%$, which represents $71.36 \%$ of all MSIs.
Of the 807 subjects studied, women reported a MSIs incidence rate of $28.22 \%$ and men presented an incidence rate of $27.13 \%$. There is no significant difference in MSIs incidence rate between gender $\chi^{2}(1)=0.02(p=0.877)$. Table 3 presents the Relative Risk (RR) analysis when the sample was stratified by gender and quartiles of age, hours of physical activities per week, and Body Mass Index (BMI).

Table 3. Relative Risk analysis for MSIs risk factors (age, hours of physical activities per week, and Body Mass Index) for 807 military from Brazilian Army, 2015.

\begin{tabular}{|c|c|c|c|c|c|}
\hline variable & Gender & Quartile & Range & $\mathbf{R R}$ & Confidence Interval \\
\hline \multirow{6}{*}{$\begin{array}{c}\text { Age } \\
\text { (years) }\end{array}$} & & 1 & $16-20$ & 1.003 & $0.705-1.426$ \\
\hline & Male & $2-3$ & $20-23$ & 1.000 & Reference \\
\hline & & 4 & $23-27$ & 1.382 & $1.015-1.883^{*}$ \\
\hline & & 1 & $17-21$ & 2.143 & $0.970-4.733$ \\
\hline & Female & $2-3$ & $21-26$ & 1.000 & Reference \\
\hline & & 4 & $26-27$ & $\mathbf{0 . 5 0 0}$ & $0.117-2.139$ \\
\hline \multirow{6}{*}{ Hours of physical activities per week (hours) } & & 1 & $2-6$ & 1.209 & $0.870-1.679$ \\
\hline & Male & $2-3$ & $6-10$ & 1.000 & Reference \\
\hline & & 4 & $10-28$ & 1.230 & $0.887-1.703$ \\
\hline & & 1 & $2-5$ & 2.050 & $0.756-5.558$ \\
\hline & Female & $2-3$ & $5-10$ & 1.000 & Reference \\
\hline & & 4 & $10-15$ & 2.392 & 0.925 - 6.187 \\
\hline Body Mass Index & Male & 1 & $\begin{array}{l}19.0- \\
22.0\end{array}$ & 1.169 & $0.839-1.627$ \\
\hline
\end{tabular}




\begin{tabular}{|c|c|c|c|c|}
\hline & $2-3$ & $22.0-$ & 1.000 & Reference \\
\hline & 4 & $\begin{array}{c}24.9- \\
32.2\end{array}$ & 1.223 & $0.884-1.692$ \\
\hline \multirow{3}{*}{ Female } & 1 & $\begin{array}{l}17.0- \\
20.1\end{array}$ & 1.281 & $0.480-3.418$ \\
\hline & $2-3$ & $\begin{array}{c}20.2- \\
25.0\end{array}$ & 1.000 & Reference \\
\hline & 4 & $\begin{array}{l}25.0- \\
30.4\end{array}$ & 1.281 & $0.480-3.418$ \\
\hline
\end{tabular}

* Statistical Significance

\section{DISCUSSION}

To the best of our knowledge, the present study is the first of this type trying to identify MSIs incidence rate and relative risk among Brazilian Army officers and sergeant students. For the same reason, the comparison of the MSIs incidence rate found of $27.13 \%$ and $28.22 \%$ for men and women respectively, with similar studies in Brazil was impaired. Previous studies in US military, the injury incidence rate have ranged from 27\% (BELL et al., 2000) and $42 \%$ for men (JONES et al., 1993; KNAPIK et al., 2013) and 30\% (Roy et al., 2014) and 57\% (Bell et al., 2000) for women. Most of these studies (JONES et al., 1993; BELL et al., 2000; KNAPIK et al., 2013) followed up the soldiers during a Basic Combat Training comprising 8 to 12 -week activity program. These short and high physical demanding program contrasts with the not so intense program of officer and sergeant training courses in Brazilian Army. That could explain why the MSIs incidence rate of $27 \%$ for men is in the lower limit range and incidence rate of $28 \%$ of women is lower than the rate found in past studies among military. As previous demonstrated (KNAPIK et al., 2007), different militaries occupational specialties have different physical demands, where those with higher physical demands shows higher injury incidence rate.

Concerning to the body region affected by MSIs, the lower extremities accounted for $68 \%$ of all injuries reported, being knee $(25.9 \%)$ and ankle $(21.3 \%)$ the most affected. Others studies (JONES et al., 1993; ALMEIDA et al., 1999; ROY et al., 2014) also reported a predominance of lower extremities injuries, with a prevalence ranging from $46.5 \%$ to $82 \%$.

Analyzing the days away from the physical training, it is possible quantify the severity of injury and the potential impact on the military healthiness and physical fitness. Although not the most common anatomical site of injury, elbow and arm accounted for the largest number of absent days from physical activity, with an average of 34 days. Knee, with an average of 24 days of absence of physical activity, has the highest incidence of injuries $(7.06 \%$ of all injuries) and grows in importance since it has the largest sum of days away from physical training. In the US military, Ruscio et al. (2010) demonstrated that lower extremities injuries were the main cause of the absence of physical activity, with an average of 14 days for overuse injuries and 120 days for fractures. In the same direction, Peake et al. (2012) showed that the amount of restricted work days by MSIs ranged from 10 to 25 days according to body weight in Australian military, although that correlation (body mass and restricted work days) was not statistically significant.

About risk factors for exercise-related injuries, although other studies have reported an extensive list of risk factors, the present study is focused on age, gender, body mass index and weekly time spent in physical activities. Of those, only older age shows a statistical significance relative risk. The finding that older militaries have higher risk than young for develop a MSIs is consistent with many others previous studies (JONES et al., 1993; HEIR; EIDE, 1997; KNAPIK et al., 2013; ROY et al., 2014). As proposed by Knapik et al. (2013), the reason for that may have to do with age-related changes in tissue repair mediated by stem cells which could make these individuals more susceptible to injuries caused by overuse. In the present study, the relative risk of 1.38 could be higher if the age range was wider, since the difference between the oldest and youngest participants was only 11 years.

Regarding to factor gender, in present study, this variable was not associated with incidence of MSIs. Bell et al. (2000) reported that gender, after controlled by level of fitness, is not significantly associated with training-related injury. In the same direction, Blacker et al. (2008) suggest that gender alone is not a significant risk factor for MSIs in female recruits. One possible reason for this lies in the fact that men and women had approximately the 
same level of fitness at the beginning of the training course, as there are eliminatory physical tests during the selection process to access these courses. Another factor that may have contributed is that the physical tests during those courses are proportional to the gender (a bit less for women).

In the analysis of body composition, although other studies in the past have shown an increased risk of MSIs for individuals in the lower and upper extremes of BMI (HEIR; EIDE, 1997), this association with injury risk was not found in this study. Other more recent studies using multivariate regression analysis, also did not find this association (ROY et al., 2014). Possibly the individuals who have the highest BMI are the same who did less physical activity and have the lower levels of physical fitness. Another factor that may have contributed to this lies is the great homogeneity of the military sample. With a mean BMI $23.53 \pm 2.00$ (standard deviation), quartile analyzed were very similar from a physiological point of view.

Activities which most contributed to MSIs were those related with military physical training or military combat simulation. In present study, as other authors reported (ROY et al., 2014), running during physical training was by far the most representative activity accounting for $43 \%$ of all injuries. We cannot disregard the fact that, at Officer and Sergeant Training Courses in Brazilian Army, the running test is one important part of the physical fitness evaluation process of the student and may have future influence on their careers in the Brazilian Army. At these courses, the highest score that a student can achieve corresponds to the 95th percentile of normative values proposed by the ACSM (2013) for the 12-minute run test. Therefore, in order to achieve better running performance, these military could carry out some kind of unbalance in the triad volume-intensity-rest, which can lead to MSIs. This idea is reinforced by (KNAPIK et al., 2013) when, despite have studied a less prolonged military course, he also identified military physical training as the leading cause of injuries during the 8-week program of Basic Combat Training for US Army recruits.

As the time spent in physical activities and all other variables were measured by a recall selfreported questionnaire, the questions were simple and easy to remember in order to avoid blank answers. So as only the total hours spent in aerobic or neuromuscular activities was requested, it was not possible to calculate the incidence relative to each subtype of activity per unit of time, making it difficult to compare with other studies. This can be cited as a limitation of this study.

From all the results found in this study, the fact of the lower extremities and running training are the main parts involved in the largest number of injuries in young soldiers. It reinforces the importance of care to avoid excessive physical training. Following the proposed by Bullock et al. (2010), the main strategy for injuries prevention is to avoid overtraining. Good evidences was found that physical training programs, especially in initial military training, when started with lower mileage and intensity reduce injury rates while maintaining or improving physical fitness.

\section{CONCLUSIONS}

For newly incorporated military, the largest amount musculoskeletal injuries occurred in the lower extremities, and during military physical training, with running being the main activity in which the injuries occurred.

Population, gender and body composition was not significantly associated with these types of injuries, while older age was associated in this study. Whole work load during the week and Gradual and systematic progression of distance and speed during running training should be emphasized to prevent MSIs.

RESUMO: A incidência de lesões musculoesqueléticas (LME) é uma preocupação constante em todas as Forças Armadas. Entre os fatores de risco para LME, treinamentos físicos e esportes podem ser considerados a causa mais frequente em militares. O objetivo deste estudo foi investigar a taxa de incidência de lesões musculoesqueléticas, identificar a distribuição anatômica e sua associação com fatores de risco, tais como: composição corporal, idade e treinamento físico nos últimos 12 meses. Trezentos e cinquenta e um cadetes do primeiro ano da Escola Preparatória de Cadetes do Exército brasileiro e quatrocentos e cinquenta e seis alunos do curso de Sargento logístico (trezentos e setenta e cinco homens e oitenta e uma mulheres) se ofereceram para preencher um questionário auto relatado que foi desenvolvido com base em uma revisão da literatura e a experiência clínica dos pesquisadores. Ele continha perguntas sobre o local anatômico das LME, horas de atividades físicas por semana, tipo de atividades no momento da lesão e dias de ausência em atividades físicas. Entre 807 sujeitos estudados, 180 militares relataram 220 LME. A partir deste total, 143 apresentaram uma única lesão, 34 sofreram duas lesões e três indivíduos tiveram três lesões cada nos últimos 12 meses. O joelho foi o local anatômico com maior incidência (7,06\%) de LME ao longo de um período de 12 meses. A corrida foi a atividade 
com maior incidência (11,77\%) de lesões ao longo de 12 meses, representando 43,18\% de todas as LME. Quando considerado todas as atividades de treinamento físico, a taxa de incidência de MSI ao longo de um período de 12 meses foi de $17,97 \%$, o que representa $71,36 \%$ de todas as LME. Em militares jovens, a maior quantidade de lesões musculoesqueléticas ocorreu nas extremidades inferiores e durante o treinamento físico militar, sendo a corrida a principal atividade na qual ocorreram as lesões. População, gênero e composição corporal não foram significativamente associados a esses tipos de lesões, enquanto a idade avançada foi associada neste estudo. A progressão gradual e sistemática da distância e da velocidade durante o treinamento em corrida deve ser enfatizada para evitar LME.

PALAVRAS-CHAVE: Lesões musculoesqueléticas. Militar. Epidemiologia. Fatores de risco. Feridas e lesões.

\section{REFERENCES}

ACSM, A. C. O. S. M. ACSM's guidelines for exercise testing and prescription. Lippincott Williams \& Wilkins, 2013. ISBN 1469826666.

ALMEIDA, S. A.; WILLIAMS, K. M.; SHAFFER, R. A. and BRODINE, S. K. Epidemiological patterns of musculoskeletal injuries and physical training. Medicine and Science in Sports and Exercise, v. 31, n. 8, p. 1176-1182, 1999. ISSN 0195-9131.

BELL, N. S.; MANGIONE, T. W.; HEMENWAY, D.; AMOROSO, P. J. and JONES, B. H. High injury rates among female army trainees: a function of gender? American journal of preventive medicine, v. 18, n. 3, p. 141-146, 2000. ISSN 0749-3797.

BLACKER, S. D.; WILKINSON, D. M.; BILZON, J. L. and RAYSON, M. P. Risk factors for training injuries among British Army recruits. Military medicine, v. 173, n. 3, p. 278-286, 2008. ISSN 1930-613X.

BULLOCK, S. H.; JONES, B. H.; GILCHRIST, J. and MARSHALL, S. W. Prevention of physical trainingrelated injuries: recommendations for the military and other active populations based on expedited systematic reviews. American journal of preventive medicine, v. 38, n. 1, p. S156-S181, 2010. ISSN 0749-3797.

BULZACCHELLI, M. T.; SULSKY, S. I.; RODRIGUEZ-MONGUIO, R.; KARLSSON, L. H. and HILL, M. $\mathrm{O}$. T. Injury during US Army basic combat training: a systematic review of risk factor studies. American journal of preventive medicine, v. 47, n. 6, p. 813-822, 2014. ISSN 0749-3797.

GOODALL, R. L.; POPE, R. P.; COYLE, J. A. and NEUMAYER, R. Balance and agility training does not always decrease lower limb injury risks: a cluster-randomised controlled trial. International journal of injury control and safety promotion, v. 20, n. 3, p. 271-281, 2013. ISSN 1745-7300.

HEIR, T. and EIDE, G. Injury proneness in infantry conscripts undergoing a physical training programme: smokeless tobacco use, higher age, and low levels of physical fitness are risk factors. Scandinavian journal of medicine \& science in sports, v. 7, n. 5, p. 304-311, 1997. ISSN 1600-0838.

JONES, B. H.; COWAN, D. N.; TOMLINSON, J. P.; ROBINSON, J. R.; POLLY, D. W. and FRYKMAN, P. $\mathrm{N}$. Epidemiology of injuries associated with physical training among young men in the army. DTIC Document. 1993

KNAPIK, J. The Importance of Physical Fitness for Injury Prevention: Part 2. Journal of special operations medicine: a peer reviewed journal for SOF medical professionals, v. 15, n. 2, p. 112, 2015. ISSN 15539768.

KNAPIK, J. J.; GRAHAM, B.; COBBS, J.; THOMPSON, D.; STEELMAN, R. and JONES, B. H. A prospective investigation of injury incidence and injury risk factors among Army recruits in military police training. BMC musculoskeletal disorders, v. 14, n. 1, p. 1, 2013. ISSN 1471-2474. 
KNAPIK, J. J.; JONES, S. B.; DARAKJY, S.; HAURET, K. G.; BULLOCK, S. H.; SHARP, M. A. and JONES, B. H. Injury rates and injury risk factors among US Army wheel vehicle mechanics. Military medicine, v. 172, n. 9, p. 988-996, 2007. ISSN 1930-613X.

KODESH, E.; SHARGAL, E.; KISLEV-COHEN, R.; FUNK, S.; DORFMAN, L.; SAMUELLY, G.; HOFFMAN, J. R. and SHARVIT, N. Examination of the Effectiveness of Predictors for Musculoskeletal Injuries in Female Soldiers. Journal of sports science \& medicine, v. 14, n. 3, p. 515, 2015.

KOTWAL, A. Training-associated injuries among Armed Forces trainees. Medical journal, Armed Forces India, v. 68, n. 2, p. 106, 2012. https://doi.org/10.1016/S0377-1237(12)60015-X

NEVES, E. B. Gerenciamento do risco ocupacional no Exército Brasileiro: aspectos normativos e práticos. Cadernos de Saúde Pública, v. 23, n. 9, p. 2127-2133, 2007. ISSN 0102-311X. 6

NEVES, E. B.; DE OLIVEIRA, A. G. V.; MACEDO, A. R. M.; DE SOUZA, M. N. and DE ALMEIDA, R. M. V. R. A Incidência de Lesões no Curso de Formação de Pára-Quedistas Militares Brasileiros. Revista UNIANDRADE, v. 11, n. 1, p. 53-64, 2010. ISSN 1519-5694.

NEVES, E. B.; DE SOUZA, M. N. and DE ALMEIDA, R. M. V. R. Military parachuting injuries in Brazil. Injury, v. 40, n. 8, p. 897-900, 2009. https://doi.org/10.1016/j.injury.2009.01.13

NEVES, E. B. and MELLO, M. G. D. S. O risco da profissão militar na cidade do Rio de Janeiro em "tempo de paz": a percepção da tropa. Ciência e Saúde Coletiva, v. 14, n. 5, p. 1699-1707, 2009.

https://doi.org/10.1590/S1413-81232009000500011

NINDL, B. C.; WILLIAMS, T. J.; DEUSTER, P. A.; BUTLER, N. L. and JONES, B. H. Strategies for optimizing military physical readiness and preventing musculoskeletal injuries in the 21 st century. US Army Medical Department Journal, v. 4, p. 5-23, 2013.

ORR, R. M.; JOHNSTON, V.; COYLE, J. and POPE, R. Reported load carriage injuries of the Australian army soldier. Journal of occupational rehabilitation, v. 25, n. 2, p. 316-322, 2015. ISSN 1053-0487.

PAPACHRISTOS, A.; EDWARDS, E.; DOWRICK, A. and GOSLING, C. A description of the severity of equestrian-related injuries (eris) using clinical parameters and patient-reported outcomes. Injury, v. 45, n. 9, p. 1484-1487, 2014. ISSN 0020-1383.

PATTUSSI, M. P.; LALLOO, R.; BASSANI, D. G. and OLINTO, M. T. A. The role of psychosocial, behavioural and emotional factors on self-reported major injuries in Brazilian adolescents: a case-control study. Injury, v. 39, n. 5, p. 561-569, 2008. ISSN 0020-1383.

PEAKE, J.; GARGETT, S.; WALLER, M.; MCLAUGHLIN, R.; COSGROVE, T.; WITTERT, G.; NASVELD, P. and WARFE, P. The health and cost implications of high body mass index in Australian defence force personnel. BMC public health, v. 12, n. 1, p. 1, 2012. ISSN 1471-2458.

RAZALI, N. M. and WAH, Y. B. Power comparisons of shapiro-wilk, kolmogorov-smirnov, lilliefors and anderson-darling tests. Journal of Statistical Modeling and Analytics, v. 2, n. 1, p. 21-33, 2011.

ROY, T. C.; SONGER, T.; YE, F.; LAPORTE, R.; GRIER, T.; ANDERSON, M. and CHERVAK, M. Physical Training Risk Factors for Musculoskeletal Injury in Female Soldiers. Military medicine, v. 179, n. 12, p. 1432-1438, 2014. ISSN 1930-613X.

RUSCIO, B. A.; JONES, B. H.; BULLOCK, S. H.; BURNHAM, B. R.; CANHAM-CHERVAK, M.; RENNIX, C. P.; WELLS, T. S. and SMITH, J. W. A process to identify military injury prevention priorities based on injury type and limited duty days. American journal of preventive medicine, v. 38, n. 1, p. S19-S33, 2010. ISSN 0749-3797. 